\title{
STRATEGIC AMBIDEXTERITY AND INNOVATION IN CHINESE MULTINATIONAL VS. INDIGENOUS FIRMS: THE ROLE OF MANAGERIAL CAPABILITY
}

\author{
Jie $\mathrm{Wu}^{*}$ \\ Faculty of Business Administration \\ University of Macau \\ Macau, China \\ Tel (853) 8397-8887 \\ Jiewu@umac.mo \\ Geoffrey Wood \\ DanCap Chair of Innovation \\ Chair of DANManagement \\ Western University \\ London, Ontario, Canada \\ $\&$ \\ Visiting Professor \\ Trinity College, Dublin, Ireland \\ gwood23@uwo.ca \\ Xiaoyun Chen \\ Faculty of Business Administration \\ University of Macau \\ Macau, China \\ xychen@umac.mo \\ Martin Meyer \\ University of Aberdeen \\ Business School \\ Aberdeen, AB24 3FX \\ $\&$ \\ Visiting Professor \\ School of Technology and Innovation \\ University of Vaasa \\ Vaasa, Finland \\ martin.meyer@abdn.ac.uk \\ Zhiyang Liu \\ Business School \\ Shanghai University of Finance and Economics \\ Room 511, No.100 Wudong Road \\ Shanghai, China \\ zhiyang163@163.com
}

*Corresponding author. email: JieWu@umac.mo

Present address: FBA, University of Macau, Avenida Padre Tomás Pereira, Taipa, Macau

Funding: The authors would like to acknowledge the financial support provided by National

Natural Science Foundation of China (No. 71728003) and University of Macau MYRG (Grant Number: 2016-00207-FBA; Grant Number: 2018-00171-FBA) for this research. 


\title{
STRATEGIC AMBIDEXTERITY AND INNOVATION IN CHINESE MULTINATIONAL VS. INDIGENOUS FIRMS: THE ROLE OF MANAGERIAL CAPABILITY
}

\begin{abstract}
In this study, we challenge the conventional understanding of ambidexterity as an unquestionable contribution to better performance. We combine the concept of ambidexterity and the notion of managerial capability to explore different effects of ambidexterity on innovation performance in the context of emerging markets. We investigate this ambidexterity-innovation effect, and how this effect is moderated by managerial capability, on a sample of 74 Chinese multinational enterprises (MNEs) vs. 60 indigenous firms that are both in high technology industries. We find that, surprisingly, ambidexterity has a negative effect on the innovation performance of indigenous firms, although this effect is less so in the case of Chinese MNEs. More importantly, strong managerial capability increases the positive effect of ambidexterity on the innovation performance of Chinese MNEs, but not so for indigenous firms. We discuss the implications of these findings on research on ambidexterity and product innovation.
\end{abstract}

Keywords: Strategic Ambidexterity; Exploration vs. Exploitation; Managerial Capability; Product Innovation; Emerging Multinational Enterprises (EMNEs); China 


\section{Introduction}

The concept of ambidexterity has been widely applied to a variety of phenomena in organizational research over the past decades. While the original meaning was defined as an individual's capacity to do two different things equally well, the more recent meaning refers to an organization's capacity to do two different things equally well, ranging from exploitation and exploration, integration and responsiveness, adaptability and alignment, efficiency and flexibility, among others. Birkinshaw and Gupta (2013) estimated that the number of studies using ambidexterity as a central concept has grown exponentially in the relatively short period between 2006 and 2012.

Despite this rapid trend and popularity, there are two lacunas in the existing literature. First, a long-standing assumption has held that ambidexterity is positively correlated with better performance. This assumption has been taken for granted without a second thought. As Birkinshaw and Gupta (2013: 293) stated, "it is almost tautological to argue that ambidexterity is correlated to performance. If a set of firms are seeking to achieve some sort of exploitation-oriented objective and also some sort of exploration-oriented objective, then the ones doing both to some degree must, by definition, outperform the ones focusing on just one of those objectives." Second, inadequate efforts have been made to explore managerial capability (i.e., how decisions are made, who is involved in decisions, how decisions are implemented, etc.) that essentially determine why some organizations are more capable than others when doing two different things equally well. As Birkinshaw and Gupta (2013: 293) stated, "If we are to really make progress on how ambidexterity is achieved we need much more insight into the nature of managerial capability." 
This study addresses these research gaps by investigating the effect of ambidexterity of exploration and exploration and innovation performance in the context of an emerging market. Specifically, we make a distinction between emerging multinational enterprises (EMNEs) and indigenous firms, because the two represent different organizational species with different market focuses, capability levels, and types. Such a distinction allows us to not only examine if ambidexterity has a consistently positive effect on performance across the two types of firms, but also how their different levels of firm-specific capabilities may moderate the ambidexterity-performance relationship. Empirically, we collected a sample of 74 Chinese multinational enterprises (MNEs) vs. 60 indigenous firms, both from high technology industries, to test the hypotheses.

This study makes several important contributions to the literature. First, we challenge the long-held assumption by revealing that the ambidexterity of exploration and exploitation does not necessarily result in positive performance. We find that ambidexterity actually has a negative effect on indigenous firms' innovation performance, but that this negative effect is less for Chinese MNEs. Second, we advance the literature in addressing the question of why some organization are more ambidextrous than others and investigating managerial capability as the boundary condition that shapes the effect of ambidexterity on emerging market firms' innovation performance. We find that strong managerial capability indeed increases the positive effect of ambidexterity on Chinese MNEs' innovation performance, but not for indigenous firms. Third, this study also contributes to the international business literature by investigating different potential relationships between ambidexterity of exploration and exploitation, managerial capability, and innovation performance of EMNEs vs. indigenous firms. These two types 
of firms represent emerging market firms that encounter different organizational conflicts that require distinct capabilities to resolve conflicts, but have seldom been examined simultaneously investigated. This study fills this gap and shows its worthiness.

\section{Theoretical Development and Hypotheses}

\section{Literature Review}

Running through the literature, three intellectual streams of ambidexterity research exist. One stream concerns the roots of ambidexterity, which could be traced to Duncan (1976), the first to use the term ambidextrous organization to describe the "dual structures" that many companies put in place to manage activities involving different time horizons and managerial capabilities. Twenty years later, Tushman and O'ReillyIII picked up the concept in their article for California Management Review (1996) and a related book (1997), but with a slightly different focus: how companies could manage both evolutionary and revolutionary change processes. Their approach followed Ducan's conceptualization and emphasized structural separation between two different types of activities. However, these approaches do not offer much on the broader managerial debate beyond structural separation, which is less applicable in coping with discontinued changes (e.g., disruptive technologies).

The second intellectual stream could be traced back to March's exploitation-exploration paradox. In his (1991) seminal paper, "Exploration and exploitation in organizational learning," March built on the notions of bounded rationality and problematic search to explicitly propose a fundamental incompatibility between exploration and exploitation for organizational learning. Framing the 
exploration-exploitation tension in a broad way attracted much attention from various scholars (e.g., Chang, 1995; Hedlund \& Ridderstrale, 1995; Levinthal \& March, 1993), who then substantially extended this theoretical anchor to a wide range of organizational phenomenon.

The third related intellectual stream could be dated to Gibson and Birkinshaw (2004) who shifted from the more structure-oriented approach to ambidexterity to a context-oriented approach. Their original focus was not ambidexterity per se, but rather in the tension between the capacity of an organization for alignment and adaptability, and the role of organizational context to help the firm achieve an appropriate level of balance. Later, the authors leaned heavily on Adler and colleagues (1999)'s ethnographic study of autoworkers balancing efficiency and flexibility at NUMMI, the GM/Toyota joint venture. They theorized contextual ambidexterity as distinct from structural ambidexterity in the way that the former emphasizes the multitude of ways, rather than structural separation, that organizations use to manage the tension involved in doing two different things at the same time.

These three intellectual streams have influenced and bolstered each other, which has resulted a dramatic increase on the topic of ambidexterity over the past four decades. These studies can be roughly classified into four stages: Stage I (1995-2005): a few initial papers that defined the concept and pinpointed its importance (e.g., Adler et al., 1999; Gibson \& Birkinshaw, 2004; He \& Wong, 2004; Tusham \& O’Reilly III, 1996); Stage II (2005-2009): a large number of papers that examined different forms of ambidexterity, as well as its antecedents and consequences and the role of various moderating mediating variables (e.g., Gupta, Smith, \& Shalley, 2006; Lubatkin, Simsek, Ling, \& Veiga, 2006); 
Stage III (2009-2013): more efforts are made to additional aspects of ambidexterity, aiming to achieve consolidation on this topic (e.g., Lavie, Stettner, \& Tushman, 2010; Raisch \& Birkinshaw, 2008); and Stage IV (2013-present): a further proliferation of papers extending the concept to other fields such as international business (e.g., this special issue of International Business Review), human resource management (e.g., Mom, Chang, Cholakova, \& Jansen, 2018), finance (e.g., Titus, House, \& Covin, 2014), marketing (e.g., Laplume, \& Dass, 2015) and other areas.

While the studies on ambidexterity have achieved rapid growth, a basic but long-ignored question emerges: Does ambidexterity always lead to a good performance? Although at first glance the question seems to be naive, it is critical for the advancement of the literature, as scholars and managers both agree that it is extremely difficult, if not impossible, for an organization to do two opposite things equally well in reality. This difficulty has been clearly acknowledged by March (1991) who noticed that an organization has a tendency to self-reinforce exploration or exploitation patterns, but not both simultaneously. Although the tension of exploration and exploitation lies in why scholars have welcomed the subject of ambidexterity, managers of most organizations still take the path of least resistance of one side over the other. For example, a manager might actively pursue exploration at the cost of exploitation (or vice versa); however, he or she could then find it difficult to resist self-reinforcing patterns to initiate creative ways of excelling at both simultaneously. As such, many organizations fail, a fact that essentially communicates the notion that not all organizations pursuing ambidexterity actually help their own performance. Birkinshaw and Gupta's (2013: 295) Figure 2 (titled "Different approaches to Managing Ambidexterity") reflects this approach, wherein many firms 
approach the efficiency frontier, but have not yet achieved it. As such, these firms are less adept at reconciling different objectives than others due to their own constraints (e.g., much weaker managerial capability). Therefore, the main task is to improve managerial capability as firms strive to move their ambidextrous ability to the efficiency frontier, thereby highlighting the importance of managerial capability as a key boundary condition when examining the effect of ambidexterity on performance outcome. In the following section, we first propose the different effects of both exploration and exploitation ambidexterity on innovation performance between Chinese MNEs vs. indigenous firms and then investigate the moderating role of managerial capability in this relationship.

\section{Effects of Ambidexterity on Innovation Performance across Chinese MNEs vs. Indigenous Firms}

In the context of emerging markets such as China, many indigenous firms are more likely to explore resources and networks (e.g., guanxi) deeply embedded in local markets that enable adeptness at circumnavigating specific contextual challenges (Kotabe et al., 2017; Kim, Wu, Schuler, \& Hoskisson, 2019). That is, such firms' competitiveness depends on exploitative capabilities in local markets that may be weakened if too much attention is devoted to securing a balance of exploration beyond local markets ( $\mathrm{Wu}, \mathrm{Lao}$, Wan, \& $\mathrm{Li}, 2019)$. It is a challenge for such indigenous firms to achieve ambidexterity (e.g., exploitation and exploration in both local and foreign markets) especially for those that have overwhelmingly focused on exploitation to expand. Such inability is further constrained by behavior routines that are self-reinforcing (Prahalad \& Bettis, 1986) and 
prior experiences that are path-dependent (March, 1991)_decisions that are jointly shaped by various stakeholders.

In contrast, many Chinese MNEs are actively expanding overseas to catch up to new technologies and develop capabilities to successfully compete on the world stage (Du and Williams, 2017; Wu \& Ang, 2019). Although they are late entrants, the modernization of the Chinese economy offers Chinese MNEs plenty of capital for overseas expansion. Successful Chinese MNEs have gradually developed the ability to exploit existing resources and capabilities developed at home and, meanwhile, to explore new capabilities to extend knowledge gained through internationalization (Junni et al., 2013). That is, many Chinese MNEs enjoy a relatively high degree of strategic ambidexterity through balancing both exploration and exploitation in domestic and foreign markets (Wu Wang, Hong, Pieropoulos \& Zhuo,, 2016). Together, we hypothesize that:

Hypothesis 1: Strategic ambidexterity of exploration and exploitation has a negative effect on the innovation performance of indigenous Chinese firms, but not of Chinese MNEs.

\section{Moderating Role of Managerial Capability}

Given that strategic ambidexterity is the organization-level ability to do two different things simultaneously, the role of manager capability in creating the conditions for ambidexterity should be taken into careful consideration (Khan, Rao-Nicholson, Akhtar, Tarba, Ahammad, \& Vorley, 2017). Managerial capability refers to the skills and administrative knowledge that organizations have accumulated to achieve effectiveness in various aspects of management. Managerial capability essentially determines why some organizations are more capable than others to perform two different tasks equally well (Birkinshaw \& Gupta, 2013). Moran and Ghoshal (1999) suggested that managers are 
more than mere players in a game to allocate resources efficiently; they are also powerful levers that enable people to productively defy the market's institutional forces.

Unfortunately, as previously noted, only inadequate efforts have been made to explore the role of managerial capability when examining the performance implications of exploration and exploitation ambidexterity. Prior studies have fused the ambidexterity and organizational learning literature to explain how managerial capability may alleviate any contradictions between exploitation and exploration (Suzuki, 2019; Junni et al., 2013). As Chinese MNEs have actively expanded overseas to explore new technologies and capabilities and transfer them to domestic markets, they have developed relatively high levels of managerial capability that enable them to perform two different things equally well. That is, managerial capability positively moderates the effect of ambidexterity on Chinese MNEs' innovation performance (Wu \& Ang, 2019). In contrast, indigenous firms constrained by local markets and limited resources have not yet developed strong managerial capabilities (Khan, Lew, \& Marinova, 2019). Although some indigenous firms have possessed a certain level of managerial capability, it is generally much weaker than that accumulated by MNEs whose successful internationalization is indispensable in developing high levels of managerial capability (Chen et al., 2016). Jajja et al. (2017) confirmed that managerial capability assumes greater importance when developing partnerships in new spheres of activities. Hence, it could be argued that:

Hypothesis 2: Managerial capability positively moderates the effect of strategic ambidexterity on Chinese MNEs' innovation performance, but less so in the case of indigenous firms.

\section{Data and Method}

\section{Sampling and Data Collection}


Following prior studies (e.g., Li and Atuahene-Gima, 2001), the sampling frame comprised data from Chinese multinational enterprises, Chinese indigenous firms, and foreign multinational enterprises (we discuss the purpose of collecting foreign multinational enterprise data in the "Robust Checks" section) based in the three most productive industrial zones in China: Beijing, Shanghai, and Shenzhen. First, we contacted High Technology Economic Zone (HTEZ) to obtain the company lists. Six hundred firms were randomly selected from over 2,000 firms in the 3 cities. We then sent e-mails to the contact persons listed on companies' webpages to explain the academic purpose of this study and invite participation. Two hundred and fifty firms out of 600 agreed to participate. We then called these firms to identify key informants such as directors, senior project managers, or equivalent executives. Three postgraduate research students were recruited as interviewers and trained for data collection.

To increase data reliability and obtain a high response rate, the research students called the key informants in each company to arrange an on-site, face-to-face interview (Wu $\&$ Chen, 2012). Over $70 \%$ of the interviews took place at the respondents' offices and lasted an average length of 30 minutes. The interviewers informed all informants of the confidentiality of their responses in advance and offered them a gift worth US\$10 (a souvenir with the university logo). To assess the quality of the responses, the interviewers asked respondents to indicate their level of knowledge about their company's strategies, performance outcomes, and industry conditions on a seven-point scale (1 = "very limited knowledge," 7 = "very substantial knowledge") (Atuahene-Gima, 2005). A mean score of 6.19 indicated that the respondents had sufficient knowledge for this study. In total, we collected 238 responses. After removing 18 responses from the analysis due to missing 
values, the study obtained a sample of 220 Chinese MNEs, with a response rate of $36.7 \%$ (220 out of 600 firms). Of these firms, 32.7\% were located in Shenzhen, $39.8 \%$ in Beijing, and $27.5 \%$ in Shanghai. In terms of firm experience, $15.9 \%$ of the firms have been operating in the industry for less than 5 years, $31.3 \%$ for five to ten years, $25.5 \%$ for 10 to 20 years, and $27.4 \%$ for over 20 years. Nearly one-third of the firms have fewer than 100 employees (30.2\%), another one-third have employee numbers ranging from 100 to 500 (32.9\%), and the remaining have more than 500 employees (36.9\%). Of the companies, 33.6\% are Chinese multinational firms, $27.3 \%$ are local Chinese firms, and $39.0 \%$ are foreign firms.

\section{Measures}

After an intensive literature review, we adapted most measures from extant studies with modifications to represent the research context of China. One author translated the measures into a Chinese version after a discussion with two Chinese management and marketing experts. A back-translation procedure was employed to verify the equivalence between the English and Chinese versions (Peng and Luo, 2000). To increase the face validity and accuracy of the terms, the authors pretested the questionnaire with 15 managers who had at least 5 years business experience in high-tech industries (Atuahene-Gima, 2005). Each manager evaluated the relevance and completeness of the measures, and the authors made necessary modifications according to their suggestions. All items as reported in the Appendix, we used seven-point Likert scales ( $1=$ strongly disagree; 7 = strongly agree).

\section{Dependent variable}


Innovation performance. Following prior studies (Baker and Sinkula, 1999), we measured innovation performance by new product performance, which involves items that addressed the market performance of new products, the speed of new product launches, and the success rate of new product launches. Respondents were asked to compare their business performance to that of their principal competitors and then rated their own firm performance in relation to their competitors. Previous studies have shown that such relative measures are not subject to product category- or industry-specific effects (Gatignon and Xuereb, 1997).

\section{Independent variable}

Exploration and exploitation ambidexterity (strategic ambidexterity). Based on prior research (He and Wong, 2004; Katila and Ahuja, 2002; Raisch and Birkinshaw, 2008; Gupta et al, 2006; Raisch and Birkinshaw, 2008), we define ambidexterity as firms' capacity to engage in exploration and exploitation simultaneously. We first developed eight items to measure explorative and exploitative strategies, focusing on how firms allocate their resources and divide their attention between exploration and exploitation. From these eight items, we then extracted two factors representing explorative and exploitative capabilities. Following prior studies (e.g., He and Wong, 2004), we computed the interaction of exploration and exploitation strategies to proxy for strategic ambidexterity. That is, when both exploitation and exploration are high, the value of their interaction is high, representing a high level of strategic exploration and exploitation ambidexterity.

We measured managerial capability by following the work of Day (1994) and Nygaard and Dahlstrom (2002), which assesses the level of a firm's mastery of 
management skills, the amount of administrative knowledge accumulated in the industry, strategy development efficiency, effectiveness of the management model, and general managers' ability in various aspects.

\section{Control variables.}

The study includes both firm level- and industry-level variables accounting for an alternative explanations. First, we controlled for firm age, which is measured by the number of years a firm has existed in its industry. Following the extant literature (e.g. He and Wong, 2004), we took the logarithm transformation to reduce the skewness of the measure. Second, we controlled for firm size, which is operationalized as the logarithm of the number of employees that a firm hires. Third, we controlled for firm-level R\&D resources, which are proxied by the number of $\mathrm{R} \& \mathrm{D}$ employees relative to the total number of employees (Richard et al., 2019). We also included industry variables to control for potential confounding influences at the sectoral level, as extant literature has suggested that such influences may affect firm performance (e.g., Chen \& Wu, 2011; Gu, Huang and Tse, 2008; Wu, 2012). To measure technological turbulence and competitive intensity, we adopted the widely used measures from prior studies (e.g., Jaworski and Kohli, 1993). Technological turbulence was composed of four items and assessed technological changes and industry developments. Competitive intensity consisted of four items appraising the level of competition in the industry. We also generated industry dummy variables $(1=$ information related high-tech industry such as information technology sector and software development sector, and $0=$ other high technology fields such as biotechnology sector and electronics product development sector).

Reliability and validity 
This study took a two-step approach to assess the reliability and validity of the measures (Anderson and Gerbing, 1988). An exploratory factor analysis (using SPSS 24.0) showed that all items had high loadings on their constructs as theoretically expected, except for one item — exploitative strategy. No substantial cross-loadings were detected after deleting this item. We then assessed the unidimensionality of the scales with the confirmatory factor analysis using AMOS 24.0 (see the Appendix). All factor loadings for the underlying constructs were significant $(p<.001)$, and the overall model fits the data satisfactorily: $\chi^{2}(208)=225.181, p=.197$; confirmatory fit index $=.994$, incremental fit index $=.994$, Tucker-Lewis index $=.992$, Goodness of fit index $=.919$; and root mean squared error of approximation $=.019$. The composite reliabilities of all main constructs were above the .60 benchmark (Bagozzi and Yi, 1988). The average variances extracted (AVE) exceeded the .50 cutoff point (Fornell and Larcker, 1981), except for one control variable, competitive intensity (.48).

The authors then ran a series of chi-square difference tests for all constructs in pairs using a constrained and an unconstrained model to assess the discriminant validity of the latent constructs. The constrained model performed significantly worse than the unconstrained model in all cases, supporting discriminant validity in all of the tests (Anderson and Gerbing, 1988). Furthermore, the average variance extracted (AVE) of each construct exceeds the squared correlations between the latent variable and every other one, thereby providing further support of discriminant validity (Fornell and Larcker, 1981).

Common method variance bias (CMV) could be a concern because the survey responses are from a single informant. To minimize CMV, we took several approaches. First, we used multiple-item constructs to capture all of the key variables because CMV is 
more problematic at the item level than at the construct level (Harrison et al., 1996).

Second, Harman's single-factor test (Podsakoff and Organ, 1986) generated a factor solution that accounts for $66.77 \%$ of the total variance, with the first factor only accounting for $20.25 \%$ of the total variance. Since a single-factor solution did not emerge and the first factor does not explain most of the variance, common method bias was not a serious concern. Last, Chang et al. (2010) pointed out that the specifications of complicated regression models reduce the potential contaminating effect of CMV because "respondents are unlikely to be guided by a cognitive map that includes difficult-to-visualize interactions" (p. 179).

\section{Analyses and Results}

Table 1 reports the descriptive statistics for the variables used in the analyses. A review of the correlations among the independent variables suggests that multicollinearity was not a major concern. Following Aiken and West's recommendation (1991), we mean-centered the independent and moderating variables to further mitigate the potential threats of multicollinearity. As the largest variance inflation factor was 3.9 (far below the benchmark of 10.0), multicollinearity was not a serious concern in our analysis.

\section{[Insert Table 1 about here]}

Table 2 reports the results of the hierarchical linear regression. Hypothesis 1 predicted that ambidexterity of exploration and exploitation has a negative effect on Chinese indigenous firms' innovation performance, but not on Chinese MNEs. As shown in Table 2, the main effect of ambidexterity on firm performance is negatively significant for Chinese indigenous firms $(\beta=-.351, p<.05)$. In contrast, despite the negative sign of 
ambidexterity, it is statistically insignificant for Chinese MNEs $(\beta=-.005, p>.1)$. The result is generally consistent with our proposition in H1. Therefore, H1 is supported.

Hypothesis 2 predicted that managerial capability positively moderates the effect of exploitation and exploration ambidexterity on Chinese MNEs' innovation performance, but less so in the case of indigenous firms. As shown in Table 2, the coefficient of the interaction term between ambidexterity and managerial capability is significantly positive $(\beta=.339, p<.01)$ for Chinese MNEs, but significantly negative for Chinese indigenous firms $(\beta=-.493, p<.05)$.

\section{[Insert Table 2 about here]}

To understand these interactions further, we plotted the significant moderating effects on the relationships between strategic ambidexterity and innovation performance using a simple slope analysis (Aiken and West, 1991). Following Aiken and West's (1991) suggestions, we set the low value of managerial capability at one standard deviation below the mean value and the high value as one standard deviation above the mean. We then substituted high and low values of managerial capability into the equation for ambidexterity and innovation performance and derived two simple regression equations. The simple slope analysis revealed some interesting findings. Figure 1 shows that for Chinese MNEs, managerial capability enhances the effects of ambidexterity on innovation performance. In other words, through building managerial capability, these firms could enhance the benefits of ambidexterity. In contrast, Figure 2 indicates that for Chinese indigenous firms, managerial capability strengthens the negative effect of exploration and exploitation ambidexterity on innovation performance. In other words, ambidexterity positively moderates the effect of ambidexterity on innovation performance of Chinese 
MNEs. Managerial capability, however, is not that useful for Chinese indigenous firms.

This finding is partly due to the fact that the indigenous firms are reluctant to use tried and trusted, but undocumented, locally developed solutions and thus are constrained by inadequate international exposure to develop necessary managerial capability. As such, many indigenous firms are far less adept at reconciling conflicts of exploitation and exploration than Chinese MNEs. These reasons, together with the abovementioned results, support $\mathrm{H} 2$.

[Insert Figure 1 and Figure 2 about here]

\section{Robust Checks}

To verify whether the discussed findings are specific to Chinese MNEs or could be generalized to other MNEs operating in China, we re-ran the analyses and compared the performance consequences between Chinese MNEs vs. MNEs from developed markets (DMNEs). Table 3 reports the results. Interestingly, we find a strong and positive association between exploration and exploitation ambidexterity and innovation performance for DMNEs $(\beta=.290, p<.05)$, which is more in line with what might be expected from a significant strand of the existing literature. Moreover, we did not find any distinct moderating effects of managerial capability on the effect exploration and exploitation ambidexterity on innovation performance for EMNEs. Together, these findings suggest that our results are novel and specific to Chinese MNEs and indigenous firms.

[Insert Table 3 about here]

\section{Discussion and Conclusion}


This study makes several important contributions to the existing ambidexterity literature. First, it challenges the existing wisdom that ambidexterity should be unquestionably associated with positive performance (Vahlne \& Jonsson, 2017). Instead, we argue the exploration-exploitation ambidexterity does not always result in a good performance, and it also depends on the kinds of organizations under examination. More importantly, the study theorizes and empirically shows that although ambidexterity has a negative effect on the innovation performance of Chinese indigenous firms, this negative effect is less in the case of Chinese MNEs. These results suggest that many Chinese indigenous firms do not have innovation benefits from conducting exploitation and exploration ambidexterity, while the negative effect becomes somewhat less pronounced in the case of Chinese MNEs, thanks to their international exposure and pressure that elevates their levels of ambidexterity to reach the efficiency frontier (Khan \& Lew, 2018). This finding is important by extending the ambidexterity literature to focus on different effects of ambidexterity on innovation by emerging market's multinationals vs. indigenous firms (Khan, Lew, \& Marinova, 2019). Although it is generally held that ambidexterity can benefit firm performance, the historical resource endowments of Chinese indigenous firms make it difficult to alter their behavioral routines and path-dependent decision making that could result in resource shortfalls, making the contingent perspective to ambidexterity of emerging market firms particularly relevant and appropriate.

Second, this study advances the literature by addressing a central question regarding why some organization are more ambidextrous than others in the context of emerging market. We pinpoint managerial capability as a key boundary condition of the effect of ambidexterity on performance. Consistent with prior studies (e.g., Wu \& Ang, 
2019; Wu, Ma, Liu, \& Lei, 2019), the results reveal that firm-specific strong capability indeed increases the positive effect of ambidexterity on Chinese MNEs' innovation performance, but not for indigenous firms. Chinese MNEs that have been exposed to world markets are likely to be further along the road of elevating their levels of ambidexterity to reach the efficiency frontier than their domestically focused counterparts. The MNEs thus have developed stronger managerial capability that enable them to move towards a better balance between exploration and exploitation, as opposed to prioritising one over the other (Kim et al., 2019). Although managerial capability positively moderates the effect of ambidexterity on Chinese MNEs' innovation performance, it is much less the case for indigenous firms. This finding may be due to indigenous firms having to depend on informal, harder to document capabilities (e.g., the ability to make effective use of extended informal networks, and to improvise solutions in the face of regulatory ambiguities).

Third, this study also contributes to the international business approach to organizational ambiderxity by investigating and comparing potential different impacts of the joint effect of ambidexterity, managerial capability, and innovation performance between emerging MNEs vs. indigenous firms. Although there is a body of excellent existing work on ambidexterity in emerging markets (e.g., Khan, Lew, \& Marinova, 2019; Khan et al., 2019), the primary focus has been on general features of ambidexterity of either EMNEs or indigenous firms. Very few studies on ambidexterity have examined both emerging MNEs and indigenous firms simultaneously or have not made a distinction between these two, and virtually no studies have revealed any important performance difference associated with ambidexterity between them. This gap is surprising because 
these two represent two different kinds of emerging market firms that encounter different organizational conflicts and, as a result, possess distinct capabilities when resolving conflicts and challenges. This study fills this gap through exploring differences in the ambidexterity-performance linkage between Chinese MNEs vs. indigenous firms. It further explores different roles that managerial capability plays in shaping the ambidexterity-performance linkage between the two types of firms.

More generally, while it has been recognized that relative organizational learning impacts the nature of ambidexterity (Swift, 2016), this study provides insights on when and how ambidexterity of exploration and exploitation is more likely to result in a positive innovation performance. The key distinctions between EMNEs and indigenous firms (e.g., the degree of internationalization, their openness to new challenges and capabilities) impacts how much ambidexterity matters, although it is acknowledged that this may also vary according to managerial capability. At a theoretical level, this study does raise issues a fundamental issue of when and how ambidexterity makes a difference to positive or negative innovation performance. As such, this study highlights the importance of investigating different types of organizations, as well as their associated levels of capabilities (e.g., Wu, Ma, Liu, \& Lei, 2019), for scholars who value ambidexterity research as they move the research agenda forward toward a unique contribution to the field of organization research.

\section{Managerial Implications}

Although ambidexterity clearly makes a difference to firm performance, this study highlights cases in which ambidexterity has a negative impact on innovation performance of Chinese indigenous firms. Given that many indigenous firms have relied heavily on their accumulated explorative capacities to attain and maintain competitive advantages 
against MNEs, the findings of this study would suggest that the development of explorative capabilities (e.g., acquire new advanced technology and knowledge) would be a priority for Chinese indigenous firms that want a sustainable competitive advantage. In addition, such firms should also strive to develop strong managerial capability that would be relevant for effective integration and balance between exploration and exploitation. These actions are likely to help indigenous firms yield the kind of dividends that MNEs have achieved. This study also suggests that managers should search beyond managerial capability for other capabilities. For example, Khan et al. (2019) found that local suppliers' absorptive capacity is critically important in spurring Pakistan manufacturers' exploitative and exploratory innovation and that learning intent enables realizes absorptive capacity. Thus, in conjunction with realized absorptive capacity, absorptive capacity supports innovation. This, together with our findings, suggests that indigenous firms in emerging markets should pay attention to other types of capabilities that play an equally important role as managerial capability in shaping the effect of ambidexterity on firm performance (space precludes a fuller assessment of this possibility). Furthermore, future researches could be beneficial by investingating whether, how and when the exploration-exploitation ambidexterity may occur across various levels from organizational level, to exclusive network level, and to non-exclusive ecosystem level (e.g., Mom, Chang, Cholakova, \& Jansen, 2018; Titus, House, \& Covin, 2014), taking account of different types of organizational structures and capabilities in enhancing or inhibiting the ability to manage new challenges and opportunites. 


\section{References}

Adler, P. S., Goldoftas, B., \& Levine, D. I. (1999). Flexibility versus efficiency: A case study of model changeovers in the Toyota production system. Organization Science, 10(1), 43-68.

Aiken, L. S., West, S. G., \& Reno, R. R. (1991). Multiple regression: Testing and interpreting interactions. Newbury Park, CA: Sage Publications.

Anderson, J. C., \& Gerbing, D. W. (1988). Structural equation modeling in practice: A review of recommended two-step approach. Psychological Bulletin, 103(3), 411-423.

Atuahene-Gima, K. (2005). Resolving the capability-rigidity paradox in new product innovation. Journal of Marketing, 69(4), 61-83.

Bagozzi, R. P., \& Yi, Y. (1988). On the Evaluation of Structural Equation Models. Journal of the Academy of Marketing Sciences, 16(1), 74-94.

Baker, W. E., \& Sinkula, J. M. (1999). The synergistic effect of market orientation and learning orientation on organizational performance. Journal of the Academy of Marketing Science, 27(4), 411-427.

Birkinshaw, J., \& Gupta, K. (2013). Clarifying the distinctive contribution of ambidexterity to the field of organization studies. Academy of Management Perspectives, 27(4), 287-298.

Chang, S. J. (1995). International expansion strategy of Japanese firms: Capability building through sequential entry. Academy of Management Journal, 38(2), 383-407. 
Chang, S. J., Van Witteloostuijn, A., \& Eden, L. (2010). From the editors: Common method variance in international business research. Journal of International Business Studies, 41(2), 178-184.

Chen, H. L., Hsu, W. T., \& Chang, C. Y. (2016). Independent directors' human and social capital, firm internationalization and performance implications: An integrated agency-resource dependence view. International Business Review, 25(4), 859-871.

Chen, X. Y. \& Wu, J. (2011). Do different guanxi types affect capability building differently? A contingent view. Industrial Marketing Management, 40(4): 581-592.

Day, G. S. (1994). The capabilities of market-driven organizations. Journal of Marketing, 58(4), 37-52.

Du, J., \& Williams, C. (2017). Innovative projects between MNE subsidiaries and local partners in China: exploring locations and inter-organizational trust. Journal of International Management, 23(1), 16-31.

Duncan, R. B. (1976). The ambidextrous organization: Designing dual structures for innovation. The Management of Organization, 1(1), 167-188.

Fornell, C., \& Larcker, D. F. (1981). Evaluating structural equation models with unobservable variables and measurement error. Journal of Marketing Research, $18(1), 39-50$.

Gatignon, H., \& Xuereb, J. M. (1997). Strategic orientation of the firm and new product performance. Journal of Marketing Research, 34(1), 77-90. 
Gibson, C. B., \& Birkinshaw, J. (2004). The antecedents, consequences and mediating role of organizational ambidexterity. Academy of Management Journal, 47(2), 209-226.

Gu, F. F., Hung, K., \& Tse, D. K. (2008). When does guanxi matter? Issues of capitalization and its dark sides. Journal of Marketing, 72(4), 12-28.

Gupta, A. K., Smith, K. G., \& Shalley, C. E. (2006). The interplay between exploration and exploitation. Academy of Management Journal, 49(4), 693.

Harrison, D. A., McLaughlin, M. E., \& Coalter, T. M. (1996). Context, cognition, and common method variance: Psychometric and verbal protocol evidence. Organizational Behavior and Human Decision Processes, 68(3), 246-261.

He, Z. L., \& Wong, P. K. (2004). Exploration vs. exploitation: An empirical test of the ambidexterity hypothesis. Organization Science, 15(4), 481-494.

Hedlund, G., \& Ridderstrale, J. (1995). Towards a theory of the self-renewing MNG. In B. Toyne \& D. Nigh (Eds.), International business: An emerging vision (Vol. 1, pp. 329-353). Columbia, SC: University of South Carolina Press.

Jajja, M. S. S., Kannan, V. R., Brah, S. A., \& Hassan, S. Z. (2017). Linkages between firm innovation strategy, suppliers, product innovation, and business performance: insights from resource dependence theory. International Journal of Operations \& Production Management, 37(8), 1054-1075.

Jaworski, B. J., \& Kohli, A .K. (1993). Market orientation: antecedents and consequences. Journal of Marketing, 57(3), 53-70. 
Junni, P., Sarala, R. M., Taras, V., \& Tarba, S. Y. (2013). Organizational ambidexterity and performance: A meta-analysis. Academy of Management Perspectives, 27(4), 299-312.

Katila, R., \& Ahuja, G. (2002). Something old, something new: A longitudinal study of search behavior and new product introduction. Academy of Management Journal, 45(6), 1183-1194.

Khan, Z., \& Lew, Y. K. (2018). Post-entry survival of developing economy international new ventures: A dynamic capability perspective. International Business Review, 27(1),149-160.

Khan, Z., Rao-Nicholson, R., Akhtar, P., Tarba, S. Y., Ahammad, M. F., \& Vorley, T. (2017). The role of HR practices in developing employee resilience: A case study from the Pakistani telecommunications sector. The International Journal of Human Resource Management, 30(8), 1342-1369.

Khan, Z., Lew, Y. K. \& Marinova, S. (2019). Exploitative and exploratory innovations in emerging economies: The role of realized absorptive capacity and learning intent. International Business Review, 28(3), 499-512.

Kim, H., Wu, J., Schuler, D. A., \& Hoskisson, R. E. (2019). Emerging multinationals' rapid internationalization: Performance advantage in one region, disadvantage in another. Journal of International Business Studies, forthcoming.

Kotabe, M., Jiang, C. X., \& Murray, J. Y. (2017). Examining the complementary effect of political networking capability with absorptive capacity on the innovative performance of emerging-market firms. Journal of Management, 43(4), 1131-1156. 
Laplume, A. O., \& Dass, P. (2015). Outstreaming for ambidexterity: Evolving a airm's core business from components to systems by serving internal and external customers. Long Range Planning, 48(3): 135-150.

Lavie, D., Stettner, U., \& Tushman, M. L. (2010). Exploration and exploitation within and across organizations. Academy of Management Annals, 4(1), 109-155.

Levinthal, D. A., \& March, J. G. (1993). Myopia of learning. Strategic Management Journal, 14(S2), 95-112.

Li, H., \& Atuahene-Gima, K. (2001). Product innovation strategy and the performance of new technology ventures in China. Academy of Management Journal, 44(6), 1123-1134.

Lubatkin, M. H., Simsek, Z., Ling, Y., \& Veiga, J. F. (2006). Ambidexterity and performance in small to medium- sized firms: The pivotal role of top management team behavioral integration. Journal of Management, 32(5), 646-672.

March, J. G. (1991). Exploration and exploitation in organizational learning. Organization Science, 2(1), 71-87.

Mom, T. J., Chang, Y. Y., Cholakova, M., \& Jansen, J. J. (2018). A multilevel integrated framework of firm HR practices, individual ambidexterity, and organizational ambidexterity. Journal of Management, 45(7): 3009-3034.

Moran, P., \& Ghoshal, S. (1999). Markets, firms and the process of economic development. Academy of Management Review, 24(3), 390-412.

Nygaard, A., \& Dahlstrom, R. (2002). Role stress and effectiveness in horizontal alliances. Journal of Marketing, 66(2), 61-82. 
Peng, M. W., \& Luo, Y. (2000). Managerial ties and firm performance in a transition economy: the nature of a micro-macro link. Academy of Management Journal, 43(3), 486-501.

Podsakoff, P. M., \& Organ, D. W. (1986). Self-reports in organizational research: Problems and prospects. Journal of Management, 12(4), 531-544.

Prahalad, C. K., \& Bettis, R. A. (1986). The dominant logic: A new linkage between diversity and performance. Strategic Management Journal, 7(6), 485-501.

Raisch, S., \& Birkinshaw, J. (2008). Organizational ambidexterity: Antecedents, outcomes, and moderators. Journal of Management, 34(3), 375-409.

Richard, O. C., Wu, J., Markoczy, L. A., \& Chung, Y. (2019). Top management team demographic-faultline strength and strategic change: What role does environmental dynamism play? Strategic Management Journal, 40(6), 987-1009.

Suzuki, O. (2019) Uncovering moderators of organisational ambidexterity: evidence from the pharmaceutical industry. Industry and Innovation, 26(4), 391-418.

Swift, T. (2016). The perilous leap between exploration and exploitation. Strategic Management Journal, 37(8), 1688-1698.

Titus, V., House, J. M., \& Covin, J. G. (2014). The influence of exploration on external corporate venturing activity. Journal of Management, 43(9):1609-1630.

Tushman, M. L., \& O'Reilly III, C. A. (1996). Ambidextrous organizations: Managing evolutionary and revolutionary change. California Management Review, 38(4) $8-29$. 
Tushman, M. L., \& O'Reilly III, C. A. (1997). Winning through innovation: A practical guide to managing organizational change and renewal. Cambridge, MA: Harvard Business School Press.

Vahlne, J. E., \& Jonsson, A. (2017). Ambidexterity as a dynamic capability in the globalization of the multinational business enterprise (MBE): Case studies of $A B$ Volvo and IKEA. International Business Review, 26(1), 57-70.

Wu, J. (2012). Technological collaboration in product innovation: The role of market competition and sectoral technological intensity. Research Policy, 41(2): 489-496.

Wu, J., \& Ang, S. H., (2019). The interaction effect of TMTs' institution-based resources on the internationalization of emerging market new ventures. Journal of World Business, forthcoming.

Wu, J. \& Chen, X.Y. (2012). Leaders' social ties, knowledge acquisition capability, and firm competitive advantage. Asia Pacific Journal of Management, 29(2): 331-350.

Wu, J., Lao, K., Wan, F., \& Li, J. (2019). Competing with multinational enterprises' entry: Search strategy, environmental complexity, and survival of local firms. International Business Review, 28(4), 727-738.

Wu, J., Ma, Z., Liu, Z., \& Lei, C. K. (2019). A contingent view of institutional environment, firm capability, and innovation performance of emerging multinational enterprises. Industrial Marketing Management, 82, 148-157.

Wu, J., Wang, C., Hong, J., Piperopoulos, P., \& Zhuo, S. (2016). Internationalization and innovation performance of emerging market enterprises: The role of host-country institutional development. Journal of World Business, 51(2), 251-263. 
Table 1. Means, Standard Deviations, and Correlations of the Constructs

\begin{tabular}{lllllllllll}
\hline & \multicolumn{1}{c}{$\mathbf{1 .}$} & $\mathbf{2 .}$ & $\mathbf{3 .}$ & $\mathbf{4 .}$ & $\mathbf{5 .}$ & $\mathbf{6 .}$ & $\mathbf{7 .}$ & $\mathbf{8 .}$ & $\mathbf{9 .}$ & $\mathbf{1 0 .}$ \\
\hline 1. Exploration & 1.00 & & & & & & & & & \\
2. Exploitation & $.18^{* *}$ & 1.00 & & & & & & & & \\
3. Strategic ambidexterity & .03 & $-.17^{*}$ & 1.00 & & & & & & & \\
4. R\&D resources & $.20^{* * *}$ & .04 & .05 & 1.00 & & & & & & \\
5. Managerial capability & $.42^{* *}$ & $.40^{* *}$ & -.13 & $.22^{*}$ & 1.00 & & & & & \\
6. Technological turbulence & $.33^{* *}$ & $.25^{* *}$ & .01 & $.21^{*}$ & $.40^{*}$ & 1.00 & & & & \\
7. Competitive intensity & $.31^{* *}$ & $.16^{*}$ & .01 & $.19^{*}$ & $.18^{*}$ & $.43^{*}$ & 1.00 & & & \\
8. Firm age & -.01 & .04 & .01 & .09 & .04 & -.07 & -.02 & 1.00 & & \\
9. Firm size & $.25^{* *}$ & -.05 & -.02 & $.85^{*}$ & $.27^{*}$ & .13 & $.18^{*}$ & .08 & 1.00 & \\
10. Innovation performance & $.22^{* *}$ & $.33^{* *}$ & .03 & .01 & $.46^{*}$ & $.15^{*}$ & -.07 & -.08 & -.01 & 1.00 \\
\hline Mean & 4.68 & 5.63 & .17 & 2.00 & 4.25 & 5.39 & 5.50 & .93 & 2.71 & 5.06 \\
S. D. & 1.06 & .87 & .91 & .97 & .84 & 1.15 & .98 & .67 & 1.01 & 1.12 \\
\hline
\end{tabular}

Notes: $\mathrm{N}=220 .{ }^{* *} p<.01,{ }^{*} p<.05$ (two-tailed) 
Table 2. Standardized Regression Coefficient Estimates

\begin{tabular}{|c|c|c|}
\hline & \multicolumn{2}{|c|}{ Innovation Performance } \\
\hline & $\begin{array}{l}\text { Chinese } \\
\text { MNEs }\end{array}$ & $\begin{array}{c}\text { Chinese } \\
\text { Indigenous } \\
\text { Firms }\end{array}$ \\
\hline \multicolumn{3}{|l|}{ Control Variables } \\
\hline Industry sector & -.056 & .020 \\
\hline Firm age & -.017 & .052 \\
\hline Firm size & -.361 & .016 \\
\hline Competitive intensity & -.149 & -.043 \\
\hline Technological turbulence & -.112 & $-.251 *$ \\
\hline$R \& D$ resources & .249 & -.047 \\
\hline Managerial capability (MC) & $.406^{* *}$ & $.645^{* *}$ \\
\hline \multicolumn{3}{|l|}{ Main Effects } \\
\hline Exploitation & .080 & -.033 \\
\hline Exploration & .020 & $.323^{*}$ \\
\hline Strategic ambidexterity (SA) & -.005 & $-.351 *$ \\
\hline \multicolumn{3}{|l|}{ Hypothesized Interactions } \\
\hline $\mathrm{SA} \times \mathrm{MC}$ & $.339 * *$ & $-.493 *$ \\
\hline Adjusted R-square & $.380^{* *}$ & $.595 * *$ \\
\hline Number of cases & 74 & 60 \\
\hline
\end{tabular}

Note: ${ }^{* *} p<.01,{ }^{*} p<.05,{ }^{+} p<.10$ (one-tailed for hypothesized interaction effect). 
Table 3. Standardized Regression Coefficient Estimates

\begin{tabular}{|c|c|c|}
\hline & \multicolumn{2}{|c|}{ Innovation Performance } \\
\hline & $\begin{array}{l}\text { Chinese } \\
\text { MNEs }\end{array}$ & $\begin{array}{c}\text { MNEs } \\
\text { of developed } \\
\text { markets }\end{array}$ \\
\hline \multicolumn{3}{|l|}{ Control Variables } \\
\hline Industry sector & -.056 & .030 \\
\hline Firm age & -.017 & -.126 \\
\hline Firm size & -.361 & .138 \\
\hline Competitive intensity & -.149 & .019 \\
\hline Technological turbulence & -.112 & -.068 \\
\hline $\mathrm{R} \& \mathrm{D}$ resources & .249 & -.094 \\
\hline Managerial capability (MC) & $.406^{* *}$ & $.359 *$ \\
\hline \multicolumn{3}{|l|}{ Main Effects } \\
\hline Exploitation & .080 & .232 \\
\hline Exploration & .020 & .044 \\
\hline Strategic ambidexterity (SA) & -.005 & $.290 *$ \\
\hline \multicolumn{3}{|l|}{ Hypothesized Interactions } \\
\hline $\mathrm{SA} \times \mathrm{MC}$ & $.339 * *$ & -.048 \\
\hline Adjusted R-square & $.380 * *$ &. $.284 *$ \\
\hline Number of cases & 74 & 86 \\
\hline
\end{tabular}

Note: ${ }^{* *} p<.01,{ }^{*} p<.05,{ }^{+} p<.10$ (one-tailed for hypothesized interaction effect). 
Figure 1.

The interactive effect of ambidexterity and managerial capability on Chinese MNEs' innovation performance.

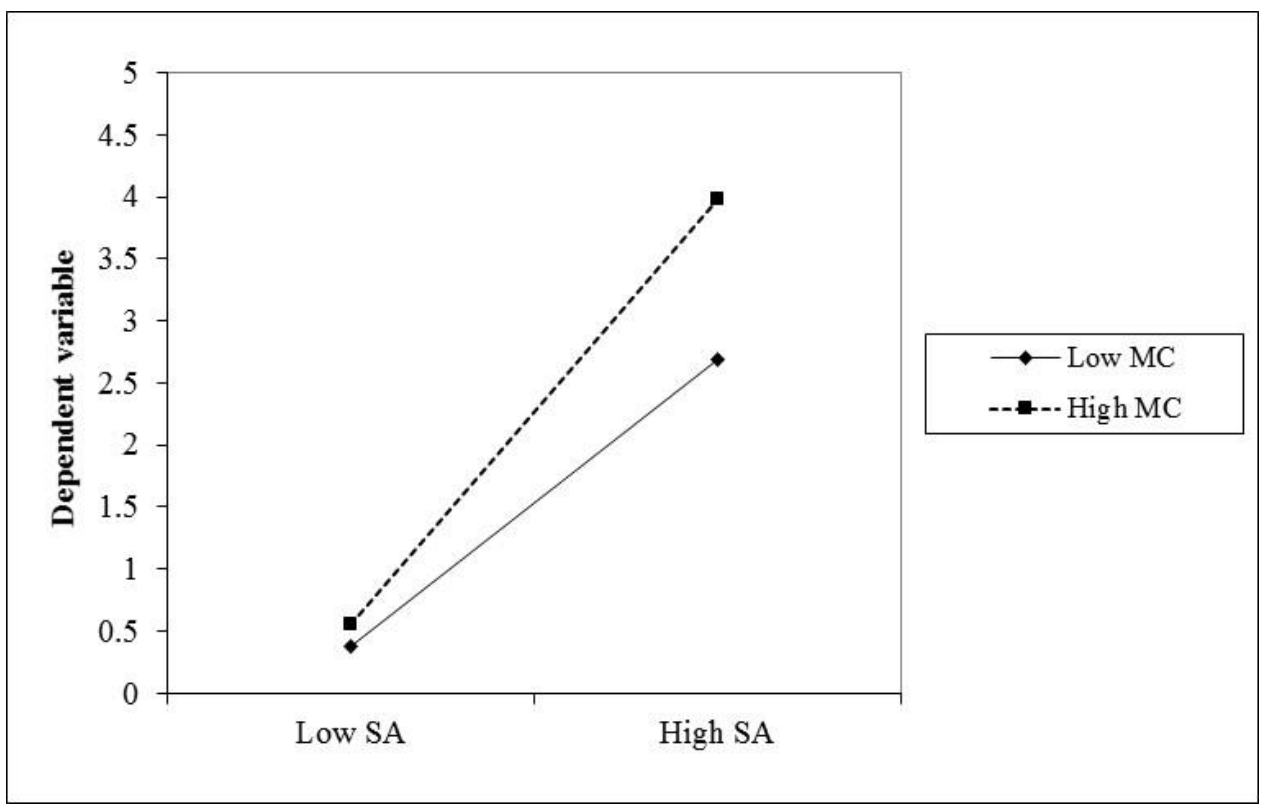


Figure 2.

The interactive effect of ambidexterity and managerial capability on Chinese indigenous firms' innovation performance.

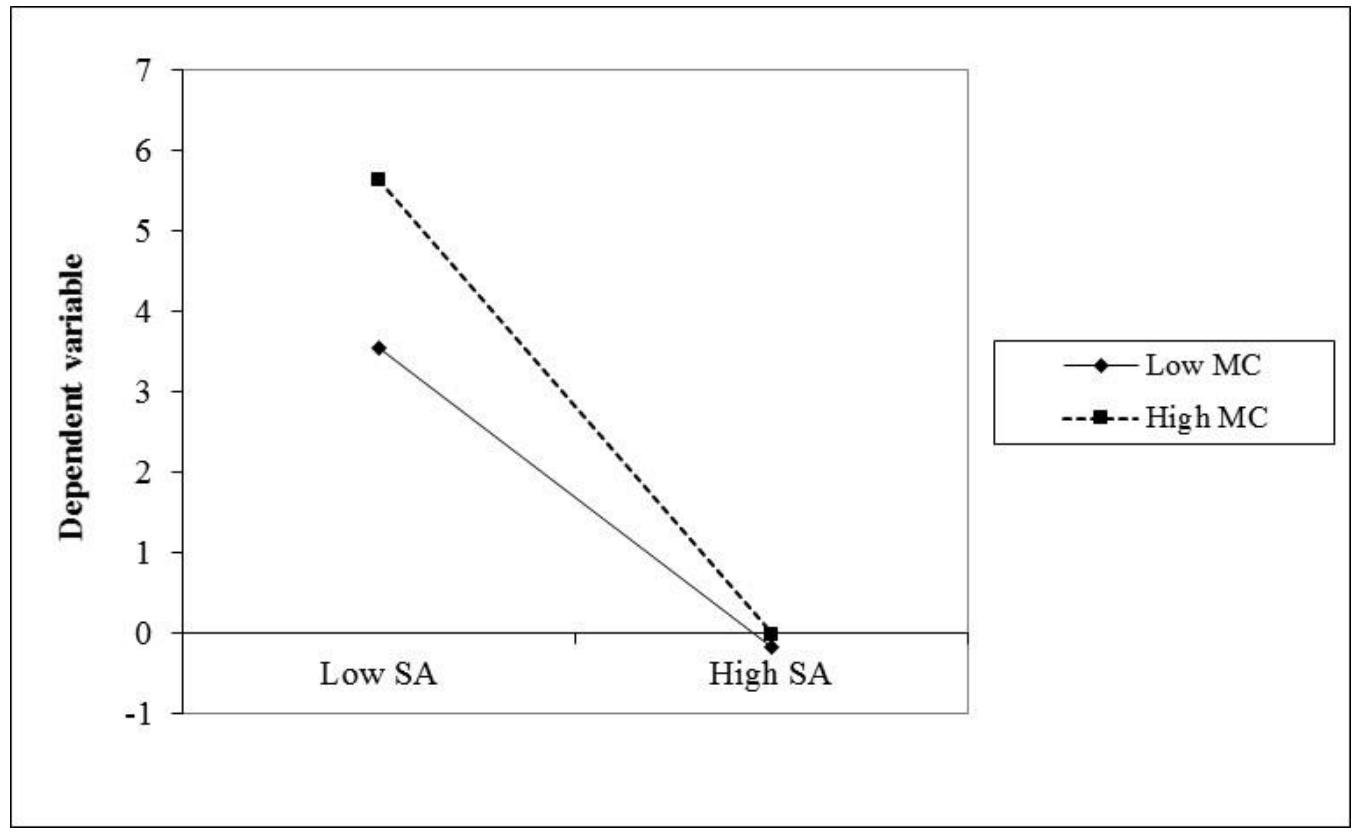




\section{Appendix: Measurement Items and Validity Assessment}

\begin{tabular}{|c|c|c|}
\hline Exploration & Cronbach's alpha $=.73 ; C R=.83 ; A V E=.55$ & Loading \\
\hline \multicolumn{3}{|l|}{ Our firm has } \\
\hline 1. Invested many financia & jects covering different product areas. & .83 \\
\hline 2. Gained a great deal of $k$ & hnologies of which we are not involved. & .94 \\
\hline 3. Invested many resource & mation from a wide range of sources. & .87 \\
\hline $\begin{array}{l}\text { 4. Actively learned variou } \\
\text { government policies \& re }\end{array}$ & $\begin{array}{l}\text { echnology, management practices, product designing, advertising, } \\
\text { ment, etc. }\end{array}$ & .66 \\
\hline Exploitation & Cronbach's alpha $=.67 ; \quad C R=.75 ; A V E=.52$ & \\
\hline \multicolumn{3}{|l|}{ Our firm has } \\
\hline 1. Committed to accumula & ologies in a single direction. & .88 \\
\hline 2. Invested many financia & logy fields in which we have expertise. & .70 \\
\hline 3. Gained thorough knowl & gies of which we are not involved. & .69 \\
\hline 4. Actively acquire knowl & luct line from clients, competitors and distributors, etc. & $*$ \\
\hline Managerial Capability & Cronbach's alpha $=.93 ; C R=.90 ; A V E=.65$ & \\
\hline \multicolumn{3}{|l|}{ Our firm } \\
\hline 1. Has mastered managem & & .74 \\
\hline 2. Has accumulated know & ficiency. & .85 \\
\hline 3. Has adopted an effectiv & & .87 \\
\hline 4. Is able to develop mana & & .90 \\
\hline 5. Is able to effectively $\mathrm{m}$ & of the company. & .84 \\
\hline \multicolumn{2}{|l|}{ Innovation Performance } & \\
\hline \multicolumn{3}{|c|}{ Relative to your principal competitors, rate your firm on: } \\
\hline 1. The quality and market & & .84 \\
\hline 2. The speed of launching & & .88 \\
\hline 3. The success rate of laur & & .87 \\
\hline
\end{tabular}

${ }^{\mathrm{a}}$ Fixed factor loading. 